\title{
A Conceptual Framework on the Audit Quality in the Government Internal Audit in Indonesia
}

\author{
Khoirul Aswar ${ }^{1}$, Ermawati ${ }^{2}$, Meilda Wiguna ${ }^{3}$, Eka Hariyani ${ }^{4}$ \\ 1,2Universitas Pembangunan Nasional Veteran Jakarta, Indonesia \\ 3,4Universitas Riau, Indonesia \\ aswar_law@yahoo.com
}

\begin{abstract}
This study begins with the problem of auditor performance on the Big Four Public Accounting Firm and requires an improvement in audit quality due to a decreased audit quality assessment on the Big Four Public Accounting Firm. Problem related to audit quality is also experienced by government internal auditors. This is due to several factors such as the minimum standards set by the Financial and Development Supervisory Agency (FDSA) that have not been met by government internal auditors, auditor staff with accounting education backgrounds are still very few, auditors have not applied the Government Internal Oversight Apparatus (GIOE) code of ethics and so forth. The aims of this study to determine the extent of the audit quality produced by the government's internal auditors at the FDSA of Java island Representatives. Through the theory of behaviorism, this study has four objectives is to find out the implementation of professional accounting ethics, auditor competence, integrity, professional commitment on audit quality. Therefore, this study contributes to FDSA of Java Provinces to carry out the functions and duties of government internal auditor based on the GIOE codes and ethics and standards.
\end{abstract}

Keywords: Audit quality, Professional accounting ethics, Professional commitment, Integrity, Auditor competency.

\section{Introduction}

Audit quality is defined as an assessment carried out by the market where there is the possibility of the auditor making a discovery of a violation in the client's accounting system and recording it. Audit quality of the public sector is an opportunity for the government internal auditor to find and report an agency or government. The audit of government institutions aims to ensure public accountability by the central or regional government or State-Owned Enterprises (BUMN)/ Local-Owned Enterprises (BUMD). The Financial Reporting Council in 2018 found that the Big Four Public Accounting Firm had a poor performance which was marked by $25.5 \%$ of audits conducted by the Big Four Public Accounting Firm that needed improvement and $14.4 \%$ of the audits had to be stopped to make improvements. Overall results show that $27 \%$ of Big Four KAPs require limited improvements. The Financial Reporting Council has determined that $90 \%$ of the targets needed for audit improvements that occur due to decreased audit quality this year. These results indicate that $73 \%$ obtained an acceptable standard which means that indicates that there is concern about the level of trust in the auditor of audit quality. Problems related to audit quality also occur in Indonesia. One of them is the Government Internal Oversight Apparatus (GIOA). The first problem is that the position of the Regional GIOA is generally under the Regional Secretary so that it weakens the oversight of GIOA. The second problem is related to the capability of GIOA that occurs because most of the GIOA are below level 1 and 2 in the Internal Audit Capability Model (IACM) index developed by Financial and Development Supervisory Agency (FDSA).

However, the minimum standard targeted by FDSA for the capabilities of GIOA is at level 3 from level 5 as the highest level of the IACM Index. The third problem lies in the paradigm applied by GIOA that occurs because the auditor only focuses on finding rather than looking at the real root of the problem. Audit quality is important because a high audit quality will produce a report that can be trusted. Audit quality is hard to measure objectively so previous research uses different measurements of audit quality. Another problem faced by government internal auditors is that not all examiners have adequate audit quality in the sense that auditors who conduct audits do not all have Auditor Functional Positions (AFP). The number of audited programs is not proportional to the number of auditors available. In addition, auditors with a background in accounting education are still very few. Related to improving audit quality, there are several studies that show factors that can influence on audit quality which is professional accounting ethics. Oraka and Okegbe (2015) and Hikmayah and Aswar (2019) concluded that professional accounting ethics had a significant influence on the audit quality. Contrary, research by Himawati, Mulatsih and Putri (2017) concluded that 
auditor ethics had a negative and not significant effect on the audit quality. Furthermore, another factor that influenced on the audit quality is auditor competency factors. Previous studies found that Auditor competence had a significantly and positively influence with the audit quality (Bouhawia, Irianto \& Baridwan, 2015; Pandoyo, 2016; Halim, Sutrisno, \& Achsin, 2014; Zahmatkesh \& Rezazadeh, 2017).

Contrary, the results by Hikmayah and Aswar (2019), Ningsih and Kiswanto (2019) shows that the auditor's, competence has a negative relationship on the audit quality. Furthermore, integrity is another factor on the audit quality. The results by Ningsih and Kiswanto (2019), Bouhawia et al. (2015), Himawati, Mulatsih and Putri (2017), Parasayu and Rohman (2014) and Kertarajasa, Marwa and Wahyudi (2019) concluded that integrity has a positive significantly relationship on audit quality. While, contrast to the results of research by Sihombing and Triyanto (2019) which states that integrity has a negative and not significant effect on the audit quality. In particular, this paper focuses on a conceptual model which will form the basis of an uncoming study in exploring the audit quality with a focus on government internal auditor at the FDSA in Java Island. This objective for this study is to determine the relationship the implementation of professional accounting ethics, auditor competence, integrity and professional commitment on the audit quality.

\section{Literature Review and Hypothesis Development}

Stewardship Theory: Stewardship theory is a theory that depicts situations in which managers are not motivated by singular objectives yet rather are focused on their fundamental result objective to serve the association with the goal that this theory has a psychological and sociological basis that has been structured in which executives as stewards are motivated to act accordingly principal's goal. Referring to the theory of stewardship, steward behavior is collective, because stewards are guided by these behaviors so that organizational goals can be achieved. Experts related to stewardship theory assume that there is a strong connection between authoritative achievement and principal satisfaction. Steward secures and maximizes shareholders through organization execution. Successful Stewards can improve company performance so that stewards can satisfy most shareholders having well-served interests through increasing the prosperity achieved by the organization. Therefore, pro-organization stewards are persuaded to amplify organization execution, in addition having the option to give the fulfillment to the interests of investors (Keay, 2017).

Attribution Theory: Attribution theory is an attempt to understand the causes behind the attitudes of other people's behavior or one's own behavior (Weiner, 1980). Attribution theory proposed by Robbin (2006), Rahmi and Sovia (2017) clarifies that an individual's conduct is brought about by inside variables or outer elements. Conduct brought about by inward factors is conduct that is accepted to be leveled out or starts from inside an individual, for example, character qualities, inspiration or capacities. Conduct brought about by outer components is conduct because of outside causes or starting from outside the individual self, for example, gear or social impact from others (hikmayah \& Aswar, 2019).

Hypothesis and Thinking Framework: The development of hypotheses in this study is based on factors that are allegedly having an influence on the audit quality, so that it can formulate as follows:

Effects of Professional Accounting Ethics on Audit Quality: A form of professionalism, especially in the fields of accounting and auditing, can show commitment to the quality of audits produced. Auditor who has high norms and ethics in accordance with APIP audit standards, are able to produce good audit quality. Research by Oraka \& Okegbe (2015), and Hikmayah \& Aswar (2019) concluded that professional accounting ethics had a positive relationship with the audit quality. Therefore, auditors are required to uphold ethics and norms and maintain professionalism in accordance with auditing standards and the APIP code of ethics (Parasayu \& Rohman, 2014). Based on the above discussion, then the hypothesis can be formulated as follows:

H1: There is a positive relationship between professional accounting ethics and the audit quality.

Effects of Auditor Competence on Audit Quality: Pandoyo (2016) said that an auditor must have good knowledge, expertise and quality personally in his field. Competence is an auditor's expertise gained from knowledge and training. Lee and Stone (1995) and Watkins et al. (2004) argued that competence have a significant relationship on the audit quality. The results by Zahmatkesh \& Rezazadeh, (2017), Pandoyo 
(2016), Sari \& Lestari (2018), Shintya, Nuryatno \& Oktaviani (2016), Kertarajasa, Marwa \& Wahyudi (2019), Bouhawia, Irianto, \& Baridwan (2015), Halim et al. (2014) found that auditor competence has significantly influence on audit quality. Every auditor must meet certain necessities to turn into an expert auditor. Auditors must be sued for ability to discover abnormalities that happen with the goal that high improve the nature of reviews delivered by the auditor (Kertarajasa et al., 2019). Based on the foregoing presumptions, the following hypothesis is stated:

H2: There is a positive relationship between auditor competence and the audit quality.

Effect of Integrity on Audit Quality: According to Parasayu \& Rohman (2014), integrity is a quality that can increase trust and as a guide for audit members to test decisions on their audit work in accordance with ethical standards. Integrity is a factor that effect on audit quality. The research by Ningsih \& Kiswanto (2019), Bouhawia et al. (2015), Himawati, Mulatsih \& Putri (2017), Parasayu \& Rohman (2014), Kertarajasa, Marwa \& Wahyudi (2019) and Hikmayah \& Aswar (2019) had provided evidence to prove that there is a positive relationship between integrity and audit quality. Auditors perform audit tasks by upholding the value of integrity, and then the audit results will be of high quality. Integrity requires the auditor to carry out his audit duties by upholding the principle of honesty, not violating the principle of the agreed audit object boundaries and can defeat personal interests. Based on the above deduction, the below hypothesis is postulated:

H3: There is a positive relationship between integrity and the audit quality.

Effect of Professional Commitment on Audit Quality: Professional commitment is an important factor that influences the behavior of auditors when facing ethical problems in conflict situations during an assignment. Commitment is needed in every profession to fulfill the need for public and stakeholder confidence in the quality of services provided by a profession (in this case as the government internal auditor (Ningsih \& Kiswanto, 2019). If this is achieved, then the audit quality produced by the auditor. This will be good and considered normal for users of financial statements. Based on the above presumptions, the below hypothesis is formulated:

H4: There is a positive relationship between professional commitment and the audit quality.

Figure 1: Research Framework

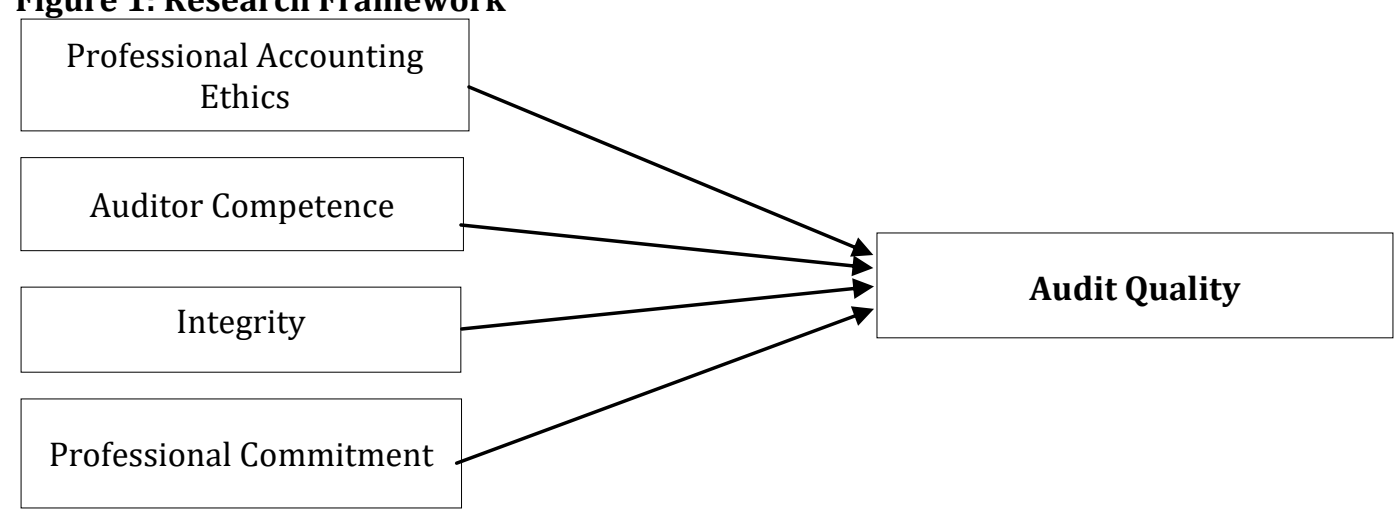

\section{Proposed Method}

This study recommends that method would be appropriate to test the proposed conceptual framework for empirical study in which data could be collected from the target respondents mostly those FDSA employees from the auditor. This is because these auditors' staff is responsible for the audit quality in the province in Indonesia. There are 333 FDSA auditors across the Java Provinces which is Province of Jakarta, Jawa Barat, Jawa Tengah, Jawa Timur and Banten. Each of five categories and their corresponding numbers are presented on table 1. 
Table 1: List of Java Provinces

\begin{tabular}{ll}
\hline Java Provinces & Number of BPKP \\
\hline Province of Jakarta & 80 \\
Province of Jawa Barat & 80 \\
Province of Jawa Tengah & 60 \\
Province of Jawa Timur & 61 \\
Province of Banten & 52 \\
Total Number of BPKP Auditors & $\mathbf{3 3 3}$ \\
\hline
\end{tabular}

\section{Conclusion}

The conceptual paper in this study aims to investigate the factors that influence audit quality in the government's internal audit, especially in the Financial and Development Supervisory Agency (FDSA) of Java Island Province. This is important because users of the audit reports conducted by government internal oversight apparatus (GIOA) need authoritative, precise and regular supervisory mechanical apparatus in completing the obligations and functions of internal auditors in government regarding with the government internal oversight apparatus code of ethics and government internal oversight apparatus audit standards. In addition, government internal oversight apparatus also aims to ensure public accountability by the central / regional government and Local Owned Enterprises (BUMN) / State Owned Enterprises (BUMD). Factors that influence audit quality are measured by 66 statements. This study finding are expected to make a significant contribution to the auditor, especially the Java Island Provincial Representative of the Financial and Development Supervisory Agency who is expected to improve ethical principles in accordance with government internal oversight apparatus standards in carrying out audit assignments and the auditor must also be responsible for any audit assignments performed by government internal auditors so that auditors still get public trust. Overall, the results of the conceptual papers in this study must also provide useful insights for FDSA auditors of Java Island Province Representatives and support the call for continued research in this exciting and unexplored area.

\section{References}

Bouhawia, M. S., Irianto, P. G. \& Baridwan, Z. (2015). The effect of working experience, integrity, competence, and organizational commitment on audit quality (Survey State Owned Companies In Libya). IOSR Journal of Economics and Finance (IOSR-JEF), 6(4), 60-67.

Halim, A., Sutrisno, T. \& Rosidi and Achsin, M. (2014). Effect of competence and auditor independence on audit quality with audit time budget and professional commitment as a moderation variable. International Journal of Business and Management Invention, 3(6), 64-74.

Hikmayah, N. \& Aswar, K. (2019). The impact of factors on the audit quality in Indonesia: The moderating effect of professional commitments. International Journal of Academic Research in Accounting, Finance and Management Sciences, 9(4), 285-293.

Himawati, D. \& Mulatsih and Putri, F. (2017). Analisis faktor-faktor yang mempengaruhi kualitas audit internal pada inspektorat jenderal kementerian pekerjaan umum dan perumahan rakyat. Forum Keuangan Dan Bisnis Indonesia, 6, 141-148.

Keay, A. (2017). Stewardhip theory: Is board accountability necessary?. International Journal of Law and Management, 59(6), 1292-1314.

Kertarajasa, A. Y., Marwa, T. \& Wahyudi, T. (2019). The effect of competence, experience, independence, due professional care, and auditor integrity on audit quality with auditor ethics as moderating variable. Journal of Accounting, Finance and Auditing Studies, 5(1), 80-99.

Lee, T. A. \& Stone, M. (1995). Competence and Independence: The Uncongenial Twins of Auditing? Journal of Business Finance and Accounting, 22(8), 1169-1177.

Ningsih, Y. \& Kiswanto. (2019). Prinsip perilaku apip, kualitas audit dan komitmen profesional sebagai moderating (studi empiris di bpkp perwakilan Jawa Tengah). Jurnal Akuntansi Pajak, 7(1), 45-58.

Oraka, A. 0. \& Okegbe, T. O. (2015). The impact of professional accounting ethics in quality assurance in audit. International Journal of Academic Research in Business and Social Sciences, 5(8), 64-78.

Pandoyo. (2016). The Effect of auditor competence, independence, audit experience, organizational culture and leadership against auditor professionalism and its implication on audit quality. International 
Journal of Advanced Research, 4(5), 1632-1646.

Parasayu, A. \& Rohman, A. (2014). Analisis faktor-faktor yang mempengaruhi kualitas hasil audit internal (studi persepsi aparat intern pemerintah Kota Surakarta dan Kabupaten Boyolali). Diponegoro Journal of Accounting, 3(2009), 1-10.

Perry, L. (1984). The SEC's Enforcement Activities. The CPA Journal, 54(4), 9-13.

Rahmi, F. \& Sovia, A. (2017). Dampak sistem pengendalian internal, perilaku tidak etis dan moralitas manajemen terhadap kecenderungan kecurangan akuntansi pada perusahaan developer di Pekanbaru. Jurnal Al-Iqtishad, 13(1), 48-66.

Sari, E. N. \& Lestari, S. (2018). Pengaruh kompetensi dan time budget pressure terhadap kualitas audit pada bpk ri perwakilan provinsi Sumatera Utara. Jurnal Riset Akuntansi Dan Keuangan, 6(1), 81-92.

Shintya, A., Nuryatno, M. \& Oktaviani, A. A. (2016). Pengaruh kompetensi, independensi dan tekanan anggaran waktu terhadap kualitas audit. Seminar Nasional Cendekiawan, 1-19.

Sihombing, Y. A. \& Triyanto, D. N. (2019). Pengaruh independensi, objektivitas, pengetahuan, pengalaman kerja, integritas terhadap kualitas audit (studi pada inspektorat provinsi Jawa Barat Tahun 2018). Jurnal Akuntansi, 9(2), 141-160.

Watkins, A. J., Hillison, W. \& Morecroft, S. E. (2005). Audit Quality: A Synthetic Theory and Empirical Evidence. Journal of Accounting Literature, 23, 153-194.

Weiner, B. (1980). A cognitive (attribution)-emotion-action model of motivated behavior: an analysis of judgments of help-giving. Journal of Personality and Social Psychology, 1, 39(2), 186-200.

Zahmatkesh, S. \& Rezazadeh, J. (2017). The effect of auditor features on audit quaity. Tekhne- Review of Applied Management Studies, 15(2), 1-9. 